University of Nebraska - Lincoln

DigitalCommons@University of Nebraska - Lincoln

USDA National Wildlife Research Center - Staff Publications
U.S. Department of Agriculture: Animal and Plant Health Inspection Service

5-10-2007

\title{
Pathophysiology of white-tailed deer vaccinated with porcine zona pellucida immunocontraceptive
}

\author{
Paul D. Curtis \\ Cornell University, pdc1@cornell.edu \\ Milo E. Richmond \\ USGS-BRD \\ Lowell A. Miller \\ USDA National Wildlife Research Center \\ Fred W. Quimby \\ Laboratory Animal Research Center, Rockefeller University, New York, NY
}

Follow this and additional works at: https://digitalcommons.unl.edu/icwdm_usdanwrc

Part of the Environmental Sciences Commons

Curtis, Paul D.; Richmond, Milo E.; Miller, Lowell A.; and Quimby, Fred W., "Pathophysiology of white-tailed deer vaccinated with porcine zona pellucida immunocontraceptive" (2007). USDA National Wildlife Research Center - Staff Publications. 711.

https://digitalcommons.unl.edu/icwdm_usdanwrc/711

This Article is brought to you for free and open access by the U.S. Department of Agriculture: Animal and Plant Health Inspection Service at DigitalCommons@University of Nebraska - Lincoln. It has been accepted for inclusion in USDA National Wildlife Research Center - Staff Publications by an authorized administrator of DigitalCommons@University of Nebraska - Lincoln. 


\title{
Pathophysiology of white-tailed deer vaccinated with porcine zona pellucida immunocontraceptive
}

\author{
Paul D. Curtis ${ }^{\mathrm{a}, *}$, Milo E. Richmond ${ }^{\mathrm{b}}$, Lowell A. Miller $^{\mathrm{c}}$, Fred W. Quimby ${ }^{\mathrm{d}}$ \\ a Department of Natural Resources, Cornell University, Ithaca, NY 14853, USA \\ ${ }^{\mathrm{b}}$ USGS-BRD, New York Cooperative Fish and Wildlife Research Unit, Cornell University, Ithaca, NY 14853, USA \\ ${ }^{\mathrm{c}}$ USDA National Wildlife Research Center, 4101 LaPorte Avenue, Fort Collins, CO 80524, USA \\ ${ }^{\mathrm{d}}$ Laboratory Animal Research Center, Rockefeller University, New York, NY 10021, USA
}

Received 13 September 2006; received in revised form 9 March 2007; accepted 20 March 2007

Available online 11 April 2007

\begin{abstract}
White-tailed deer ( $n=14$ treated, $n=7$ control) were examined postmortem to identify any possible pathophysiology resulting from PZP immunocontraception vaccination. Deer were treated twice in 1997; given a booster in 1998, with six being revaccinated in September 2000. Granulomas were found at injection sites of most deer, even 2 years post-treatment. Eosinophilic oophoritis occurred in 6 of 8 (75\%) deer vaccinated in 1998, and 3 of $6(50 \%)$ revaccinated in 2000. The 2000 revaccinates without oophoritis, had significantly fewer normal secondary follicles than control females $(P=0.03)$, and deer in the1998 treatment group $(P=0.04)$. PZP immunocontraceptive vaccine elicited ovarian pathologies in deer similar to those observed in other species.
\end{abstract}

(C) 2007 Elsevier Ltd. All rights reserved.

Keywords: Immunocontraception; Porcine zona pellucida; White-tailed deer

\section{Introduction}

Porcine zona pellucida (PZP) antigen has been the most commonly used immunocontraceptive agent for fertility control in female mammals $[1,2]$ and has been administered to 112 species of wildlife, including many ungulate species [3]. Previous investigators have reported the success and reversibility of PZP vaccination with minimal effect on the health of white-tailed deer (Odocoileus virginianus) [4-6]. Similarly, Curtis et al. [7] were successful in reducing fawn production of white-tailed deer after treatment with PZP immunocontraceptive vaccine.

Kirkpatrick and Rutberg [8] stated that, "the absence of significant health side effects" is an important characteristic of any contraceptive vaccine. Concerns about ovarian malfunction in early PZP trials on other species [9-14] prompted McShea et al. [4] to conduct histological examinations of

\footnotetext{
* Corresponding author. Tel.: +1 607255 2835; fax: +1 6072552815 . E-mail address: pdc1@ cornell.edu (P.D. Curtis).
}

ovaries from PZP-vaccinated white-tailed deer, and Miller et al. [15] to monitor progesterone levels throughout their study. No significant ovarian abnormalities were reported for treated deer that recovered to normal fertility. Since that time, a study was conducted on domestic sheep (Ovis aries), a cervid species that demonstrated marked changes in estrous cycling and hormone levels associated with severely pathologic ovaries [16]. Species- and breed-specific responses to PZP vaccinations vary both in successful fertility control, and in pathologic symptoms $[10,12,13,16-20]$. Consequently, we present information that is important for evaluation of potential animal health issues associated with the use of PZP contraceptive vaccines on white-tailed deer.

We conducted detailed necropsy of white-tailed deer to examine potential pathological impacts resulting from a successful immunocontraceptive vaccination regimen [7]. The deer we examined were still under the influence of PZP treatment, had detectable levels of PZP antibodies, and many had not demonstrated full recovery to normal fertility. Pathological effects of PZP treatment 2 years post-vaccination were 
compared to a sub-sample of deer revaccinated within one month of necropsy, and untreated deer. Our objectives were to document ovarian abnormalities or other potential health concerns resulting from the Curtis et al. [7] PZP vaccination protocol compared to control deer.

\section{Materials and methods}

Postmortem examinations were performed promptly on a sample of white-tailed deer in accordance with a protocol (No. 96-10-99) amendment approved by the Cornell University Institutional Animal Care and Use Committee. The deer had been injected with a porcine zona pellucida vaccine (PZP, $n=14$ ), or left untreated (controls; $n=7$ ) during the period 1997-2000 as a part of a fertility control study conducted on free-ranging deer contained in a 263-ha fenced, natural area at Seneca Army Depot near Romulus, New York [7].

\subsection{Vaccine formulation}

Female deer were immunized with native porcine zona pellucida prepared by and purchased from B. Dunbar (Baylor College of Medicine, Houston, TX) [20-22]. A 1-cc prime dose of PZP vaccine consisted of $0.5 \mathrm{cc}$ saline containing $100 \mu \mathrm{g}$ PZP mixed with $0.5 \mathrm{cc}$ Complete Freund's Adjuvant (CFA). Similarly, the 1-cc booster dose contained $100 \mu \mathrm{g}$ PZP in $0.5 \mathrm{cc}$ saline, mixed with Incomplete Freund's Adjuvant (IFA) at a $1: 1$ ratio $[5,15]$.

\subsection{Vaccination protocol}

The primary vaccination $(\mathrm{PZP}+\mathrm{CFA})$ was injected by hand into the hip region of female deer during winter 1997 as they were captured for recruitment into the study. At the time of capture, deer were marked with numbered ear tags and neck collars. Age was determined by the extent of tooth wear [23], and deer were released into the fenced study area. The first booster shot (PZP + IFA) was administered remotely via dart rifle with self-injecting 1-cc darts (Pneu Dart Inc., Williamsport, PA) prior to breeding season, 5-7 months later in September 1997. A second booster treatment (PZP + IFA) was delivered via dart rifle in September and October 1998. Booster treatments were suspended until September 2000 when six female deer were revaccinated (PZP + IFA) to provide the comparison of recently-vaccinated deer to those previously treated 2 years earlier.

\subsection{Deer collection and gross necropsies}

In October 2000, within permit authority from the New York State Department of Environmental Conservation (NYSDEC), deer were humanely killed by a shot to the head or neck from a high-powered rifle fired from a blind or a vehicle [24]. Blood samples were immediately collected via heart puncture at the time of death and were stored in vials on ice for transport. Deer $(n=21)$ were quickly transported within $2 \mathrm{~h}$ after collection to the Cornell University College of Veterinary Medicine and placed in a cooler at $4.4{ }^{\circ} \mathrm{C}$. Most necropsies were performed the day the deer were collected. Gross examinations included evaluation of body condition and bone marrow fat [25], examination of injection sites, and documentation of any visible abnormalities. Ovaries, internal iliac lymph node, popliteal lymph node, and thyroid glands were stripped of fat and connective tissue then weighed immediately (nearest mg). Histological analysis was performed on tissues fixed in formalin, embedded in paraffin, cut to $7 \mu$ thickness, and stained with hemotoxylin and eosin, Masson's Trichrome, or acid fast stains.

\subsection{Serology}

Blood chemistry analysis was performed by the Cornell University College of Veterinary Medicine, Animal Health Diagnostic Center on all of the collected deer. Anti-PZP titers $\left(\right.$ titer $\left.^{-1} \times 1000\right)$ titers were determined via an enzyme-linked immunosorbent assay (ELISA) as described by Miller et al. [15] and were compared to ovarian weights and histology.

\subsection{Follicle classification}

Each ovary was halved before fixation in formalin, and each half was embedded in paraffin. Multiple sections (but not step sections) were made of each surface to be examined with several stains, and if a suspected lesion was observed grossly, a section was also made through the lesion. The total number of secondary and Graafian follicles were enumerated from two cross-sectional slices from each ovary from each deer. Follicles with greater than $10 \%$ apoptotic granulosa cells were classified as atretic. Apoptosis was characterized as granulosa cells with dark, small consolidated (hyperchromatic) nuclei with an absence of heterochromatin. Likewise, any normal appearing follicle having the presence of a corona radiata or total follicular size greater than $0.5 \mathrm{~cm}$ was classified as a Graafian follicle.

A single layer of cuboidal epithelia lined several large fluid filled follicles. Because none of these follicles exceeded $1 \mathrm{~cm}$ in diameter, they were classified as atretic Graafian follicles; however, they could have been small follicular cysts. Some larger Graafian follicles with diminished numbers of granulosa cells may have also been early follicular cysts. However, we found no advanced cyst to confirm this.

\section{Results}

\subsection{Average age when euthanized}

At the time of necropsy, the mean age for control deer was 5.5 years. The 1998 treatment group also had a mean 
age of 5.5 years, and the deer revaccinated in 2000 averaged 6.5 years old. The age differences were not significant $\left(F_{2,18}=1.90, P=0.18\right)$.

\subsection{Body condition and fat reserves}

On the basis of body weight, external visibility of individual rib bones, and subcutaneous fat observed during gross necropsy, most animals were judged in good to excellent condition and had $85 \%$ or more bone marrow fat. However, there were three exceptions. Deer number 188 (1998 PZP vaccinate) had very good teeth and plenty of rumen ingesta, but she exhibited classic signs of malnutrition normally seen in deer struggling through an extremely harsh winter (poor body condition, $<50 \%$ fat score, and a gelatinous bone marrow). The other deer with depleted bone marrow fat, number 146 (1998 PZP treatment), and number 323 (control female), had good to excellent body condition.

\subsection{Injection sites}

Injection sites for 2000 revaccinates were compared to those for 1998 vaccinates to evaluate the persistence of dartsite lesions. While abscesses were more evident and larger in 2000 revaccinates, granulomas could be found at the injection site of nearly all treated deer.

\subsection{Lactation}

Five of seven $(71 \%)$ control females, and five of eight deer $(63 \%)$ receiving their last vaccination in 1998 showed evidence of lactation during summer 2000 prior to the collection. Three of the five (60\%) lactating does were also later identified as having eosinophilic oophoritis. None of the 2000 revaccinates showed evidence of lactation during necropsies.

\subsection{Blood chemistry}

There were few differences in blood chemistry between control and PZP-treated females (Table 1). Some variation occurred for selected blood parameters. However, these values fell within normal ranges and were unremarkable. There were significantly different titer levels between the groups $\left(F_{2,17}=42.32, P \leq 0.0001\right)$ with the highest titers in the 2000 revaccinates (Table 2).

\subsection{Ovarian weights}

There were also no significant differences in ovarian weights between controls, 1998 vaccinates, or 2000 revaccinates (left, $F_{3,17}=0.53, P=0.67$ and right, $F_{3,17}=0.78$, $P=0.52$; Table 2). Furthermore, there was no difference in

Table 1

Means, standard errors, and $t$-test statistics for blood parameters of female white-tailed deer in Control and PZP-treated groups at Seneca Army Depot, Romulus, New York, 2000

\begin{tabular}{|c|c|c|c|c|}
\hline Blood parameter & Control group & PZP group & $t$-Test & $P$-value \\
\hline Sodium (mEq/L) & $141.00 \pm 1.48$ & $141.21 \pm 1.33$ & $t=0.09$ & $P=0.93$ \\
\hline Potassium (mEq/L) & $11.77 \pm 0.97$ & $11.14 \pm 1.01$ & $t=0.37$ & $P=0.72$ \\
\hline Chloride $(\mathrm{mEq} / \mathrm{L})$ & $103.50 \pm 2.11$ & $101.21 \pm 1.04$ & $t=1.09$ & $P=0.29$ \\
\hline Bicarbonate $(\mathrm{mEq} / \mathrm{L})$ & $23.00 \pm 2.21$ & $23.57 \pm 0.74$ & $t=0.32$ & $P=0.75$ \\
\hline Anion gap (mEq/L) & $26.33 \pm 4.18$ & $27.64 \pm 1.56$ & $t=0.37$ & $P=0.72$ \\
\hline Urea-N (mg/dL) & $8.00 \pm 1.51$ & $13.14 \pm 1.19$ & $t=2.48$ & $P=0.02$ \\
\hline Creat-rb (mg/dL) & $1.27 \pm 0.12$ & $1.72 \pm 0.10$ & $t=2.53$ & $P=0.02$ \\
\hline Calcium (mg/dL) & $9.75 \pm 0.21$ & $9.41 \pm 0.24$ & $t=0.86$ & $P=0.40$ \\
\hline Phosphate (mg/dL) & $8.75 \pm 1.11$ & $8.70 \pm 0.68$ & $t=0.04$ & $P=0.97$ \\
\hline Magnes-xb (mg/dL) & $2.55 \pm 0.09$ & $2.69 \pm 0.12$ & $t=0.69$ & $P=0.50$ \\
\hline TotProt $(\mathrm{g} / \mathrm{dL})$ & $6.32 \pm 0.36$ & $6.56 \pm 0.20$ & $t=0.63$ & $P=0.54$ \\
\hline Alb-blk (g/dL) & $3.13 \pm 0.14$ & $3.13 \pm 0.05$ & $t=0.04$ & $P=0.97$ \\
\hline Globulin (g/dL) & $3.18 \pm 0.22$ & $3.43 \pm 0.19$ & $t=0.74$ & $P=0.47$ \\
\hline $\mathrm{A} / \mathrm{G}$ & $1.00 \pm 0.04$ & $0.95 \pm 0.05$ & $t=0.56$ & $P=0.58$ \\
\hline Glucose (mg/dL) & $186.00 \pm 82.08$ & $149.86 \pm 25.85$ & $t=0.55$ & $P=0.59$ \\
\hline AST/PST (U/cL) & $11.47 \pm 5.29$ & $31.53 \pm 13.22$ & $t=0.97$ & $P=0.35$ \\
\hline $\mathrm{SDH}(\mathrm{U} / \mathrm{L})$ & $67.18 \pm 13.56$ & $125.58 \pm 47.91$ & $t=0.78$ & $P=0.45$ \\
\hline Alk Phos (U/L) & $197.87 \pm 132.52$ & $83.71 \pm 10.44$ & $t=1.34$ & $P=0.20$ \\
\hline GGT (U/L) & $45.33 \pm 2.80$ & $56.14 \pm 3.94$ & $t=1.70$ & $P=0.11$ \\
\hline Tot Bili (mg/dL) & $0.17 \pm 0.02$ & $0.26 \pm 0.05$ & $t=1.33$ & $P=0.20$ \\
\hline Dir Bili (mg/dL) & $0.05 \pm 0.03$ & $0.13 \pm 0.04$ & $t=1.32$ & $P=0.21$ \\
\hline Ind Billi (mg/dL) & $0.12 \pm 0.03$ & $0.12 \pm 0.02$ & $t=0.03$ & $P=0.97$ \\
\hline $\mathrm{CK}(\mathrm{U} / \mathrm{cL})$ & $130.10 \pm 66.44$ & $459.32 \pm 200.61$ & $t=1.05$ & $P=0.31$ \\
\hline Iron $(\mu \mathrm{g} / \mathrm{dL})$ & $155.67 \pm 18.30$ & $182.64 \pm 13.38$ & $t=1.14$ & $P=0.27$ \\
\hline Tibc $(\mu \mathrm{g} / \mathrm{dL})$ & $318.67 \pm 28.24$ & $342.00 \pm 26.42$ & $t=0.52$ & $P=0.61$ \\
\hline Sat $(\%)$ & $48.50 \pm 3.18$ & $79.93 \pm 28.11$ & $t=0.72$ & $P=0.48$ \\
\hline Lipemia & $32.50 \pm 8.48$ & $24.57 \pm 5.82$ & $t=0.76$ & $P=0.46$ \\
\hline Hemolysis & $103.83 \pm 34.68$ & $196.14 \pm 71.17$ & $t=0.82$ & $P=0.42$ \\
\hline
\end{tabular}

Note: A Bonferroni-corrected ( $n=28$ tests) alpha level of 0.05 is 0.002. 
Table 2

Weights (mg) of left and right ovaries, PZP antibody titers and incidence of oophoritis for control and PZP treated female white-tailed deer at Seneca Army Depot, Romulus, New York, 2000

\begin{tabular}{|c|c|c|c|c|c|}
\hline ID & Treatment group & LT ovary (mg) & RT ovary (mg) & Titer $(1 /$ Titer $\times 1000)$ & Oophoritis \\
\hline 19 & Control & 573 & 606 & 0 & $\mathrm{~N}$ \\
\hline 21 & Control & 512 & 768 & 0 & $\mathrm{~N}$ \\
\hline 84 & Control & 507 & 324 & 0 & NS \\
\hline 98 & Control & 689 & 523 & 0 & $\mathrm{~N}$ \\
\hline 148 & Control & 503 & 491 & 0 & $\mathrm{~N}$ \\
\hline 323 & Control & 408 & 306 & 0 & $\mathrm{~N}$ \\
\hline 378 & Control & 325 & 462 & 0 & $\mathrm{~N}$ \\
\hline Means & & 502.4 & 497.1 & & \\
\hline 144 & 1998 & 870 & 725 & 32,000 & $\mathrm{Y}$ \\
\hline 146 & 1998 & 408 & 476 & 16,000 & $\mathrm{~N}$ \\
\hline 157 & 1998 & 922 & 1117 & 64,000 & $\mathrm{Y}$ \\
\hline 159 & 1998 & 362 & 372 & 128,000 & $\mathrm{Y}$ \\
\hline 178 & 1998 & 1152 & 1130 & 64,000 & $\mathrm{Y}$ \\
\hline 180 & 1998 & 536 & 545 & 64,000 & $\mathrm{Y}$ \\
\hline 182 & 1998 & 299 & 437 & 16,000 & $\mathrm{Y}$ \\
\hline 188 & 1998 & 451 & 480 & 32,000 & $\mathrm{~N}$ \\
\hline Means & & 625.0 & 660.2 & 52,000 & \\
\hline \multicolumn{6}{|l|}{ With eosinophils } \\
\hline 107 & 2000 & 819 & 601 & NS & $\mathrm{N}$ \\
\hline 109 & 2000 & 428 & 435 & $>128,000$ & $\mathrm{~N}$ \\
\hline 142 & 2000 & 367 & 464 & $>128,000$ & $\mathrm{~N}$ \\
\hline Means & & 538.0 & 500.0 & & \\
\hline \multicolumn{6}{|c|}{ Without eosinophils } \\
\hline 1 & 2000 & 451 & 669 & 128,000 & $\mathrm{Y}$ \\
\hline 55 & 2000 & 464 & 430 & 128,000 & $\mathrm{Y}$ \\
\hline 122 & 2000 & 477 & 605 & $>128,000$ & $\mathrm{Y}$ \\
\hline Mean & & 464.0 & 568.0 & & \\
\hline Total 2000 mean & & 501.0 & 534.0 & & \\
\hline
\end{tabular}

gross ovarian weights between the 2000 revaccinated deer with and without oophoritis ( $P=0.70$ left and $P=0.71$ right $)$.

\subsection{Oophoritis}

Eosinophilic oophoritis was frequently observed in atretic follicles of PZP-vaccinated females, and only seen in one solitary follicle from a control female. Among 1998 vaccinates 6 of 8 females (75\%) had follicular infiltrates, and among 2000 revaccinates, 3 of $6(50 \%)$ showed similar follicular infiltration (Table 3).

\subsection{Follicle counts}

There was no obvious trend or difference among the mean count of Graafian follicles between treatments $\left(F_{2,18}=0.68\right.$, $P=0.52$ ). The only significant difference observed was a lower average number of normal secondary follicles for the deer revaccinated in 2000 when compared to the control females $(P=0.04)$ and 1998 vaccinates $(P=0.04$; Table 3$)$. When the 2000 revaccinate group was subdivided into those deer exhibiting oophoritis and those without oophoritis, only the group without oophoritis had significant reduction in the number of normal secondary follicles compared to the con- trols $(P=0.03)$ and the 1998 treatment group $(P=0.04)$. The presence or absence of oophoritis among 2000 vaccinates did not correlate with ovarian weight, nor the total number of normal follicles per ovary.

\subsection{Parasites and multifocal lymphocytic infiltrates}

One deer was found with meningeal worms (Parelaphostrongylus tenuis; no. 178, 1998 treatment group), and two had hepatic cysticerci (most likely Echinococcus granulosus; no. 55,2000 treatment group, and no. 378, control group). These animals were in good to excellent body condition. Focal infiltrates and non-giant cell granulomas were seen in kidney, skeletal muscle, and liver. These lesions were consistent with immune attack against migrating parasites in tissues.

\section{Discussion}

\subsection{Depleted bone marrow fat}

Reduced fat content of bone marrow in PZP-treated deer was first observed by pathologists at the Cornell University College of Veterinary Medicine while conducting a necropsy 
Table 3

Ovarian follicle development for control and PZP-treated female white-tailed deer at Seneca Army Depot, Romulus, New York, 2000

\begin{tabular}{|c|c|c|c|c|c|c|c|c|c|}
\hline \multirow[b]{2}{*}{ ID } & \multirow{2}{*}{$\begin{array}{l}\text { Treatment } \\
\text { Group }\end{array}$} & \multicolumn{3}{|c|}{ Secondary follicles } & \multicolumn{3}{|c|}{ Graffian follicles } & \multirow[t]{2}{*}{ Eosinophilic oophoritis } & \multirow[t]{2}{*}{ Hyaline arteries } \\
\hline & & Normal & Atretic & $\%$ Atretic & Normal & Atretic & $\%$ Atretic & & \\
\hline 19 & Control & 8 & 8 & 50 & 3 & 1 & 25 & No & Yes \\
\hline 21 & Control & 16 & 1 & 5 & 1 & 4 & 80 & No & Yes \\
\hline 84 & Control & 9 & 14 & 60 & 0 & 0 & - & Yes 1 follicle & Yes \\
\hline 98 & Control & 11 & 13 & 54 & 0 & 3 & 100 & No & Yes \\
\hline 148 & Control & 6 & 17 & 73 & 0 & 1 & 100 & No & No \\
\hline 323 & Control & 4 & 8 & 66 & 0 & 1 & 100 & No & No \\
\hline 378 & Control & 3 & 11 & 78 & 0 & 1 & 100 & No & Yes \\
\hline Means & & 8.1 & 10.3 & 55 & 0.6 & 1.6 & 72 & $1 / 7$ & $5 / 7$ \\
\hline 144 & 1998 & 18 & 34 & 65 & 0 & 1 & 100 & Yes & No \\
\hline 146 & 1998 & 10 & 15 & 60 & 1 & 4 & 80 & No & No \\
\hline 157 & 1998 & 6 & 16 & 72 & 0 & 4 & 100 & Yes & Yes \\
\hline 159 & 1998 & 2 & 6 & 60 & 0 & 1 & 100 & Yes & Yes \\
\hline 178 & 1998 & 5 & 17 & 79 & 1 & 4 & 80 & Yes & Yes \\
\hline 180 & 1998 & 13 & 13 & 50 & 2 & 0 & 0 & Yes & Yes \\
\hline 182 & 1998 & 1 & 6 & 66 & 1 & 3 & 75 & Yes & Yes \\
\hline 188 & 1998 & 7 & 10 & 58 & 1 & 1 & 50 & No & Yes \\
\hline Means & & 7.8 & 14.6 & 63.8 & 0.8 & 2.3 & 73.1 & $6 / 8$ & $6 / 8$ \\
\hline \multicolumn{10}{|l|}{ Without eosinophils } \\
\hline 107 & 2000 & 2 & 12 & 85 & 1 & 4 & 80 & Yes & No \\
\hline 109 & 2000 & 8 & 20 & 71 & 0 & 1 & 100 & Yes & No \\
\hline 142 & 2000 & 2 & 6 & 75 & 1 & 2 & 66 & Yes & Yes \\
\hline Means & & 4 & 12.7 & 77 & 0.7 & 2.3 & 82 & $3 / 3$ & $1 / 3$ \\
\hline \multicolumn{10}{|l|}{ Without eosinophils } \\
\hline 1 & 2000 & 1 & 6 & 88 & 0 & 2 & 100 & No & Yes \\
\hline 55 & 2000 & 0 & 7 & 100 & 0 & 0 & - & No & Yes \\
\hline 122 & 2000 & 1 & 8 & 88 & 0 & 1 & 100 & No & Yes \\
\hline Means & & 0.7 & 7.0 & 92 & 0 & 1 & 100 & $0 / 3$ & $3 / 3$ \\
\hline Means revaccinates & & 2.3 & 9.8 & 84.5 & 0.3 & 1.7 & 89.2 & $3 / 6$ & $4 / 6$ \\
\hline
\end{tabular}

on a single PZP-vaccinated deer from Irondequoit, New York [26]. The total sample of treated deer examined was small, and these results were not published.

Bone marrow fat is normally the last energy reserve used in severe cases of malnutrition during winter [25,27]. Even fawns confined to a restricted energy diet for 10 weeks during the fall showed no significant difference in reserves of bone marrow fat compared to fawns offered feed ad libitum during the same time period $[28,29]$. Therefore, it is very unusual to see marrow fat depleted while the deer are otherwise in good to excellent body condition. The small number of PZPtreated deer examined to date makes it difficult to isolate a possible cause. Poor marrow fat content was also observed in one control deer, further complicating possible explanations. Additional investigation of the frequency and possible causes for marrow fat depletion should be conducted, considering that all cellular elements of blood develop from hematopic stem cells in the bone marrow, including leukocytes, and $\mathrm{T}$ and B lymphocytes of the adaptive immune system [30].

\subsection{Injection site and other abscesses}

A variety of infectious, parasitic, and non-inflammatory lesions were described in these deer. Most remarkable was the formation of granulomas at the injection site with all the characteristics of tuberculosis. These granulomas were characterized by the presence of a necrotic core surrounded by mixed inflammatory cells and fibrous connective tissue. All granulomas had Langerhans giant cells typical of tuberculosis. Likewise, giant cell inflammation was seen in the regional (popliteal) and deep (internal iliac) lymph nodes draining these sites. Typical acid fast bacilli were documented in these giant cells and were still apparent in the lesions and lymph nodes 2 years following injections. These types of inflammations, including the production of multinucleated giant cells associated with the presence of Mycobacteria in the adjuvant, have been previously described in other species vaccinated with Freund's Complete Adjuvant [19,31-34].

\subsection{Lactation}

Residual milk, in even a completely involuted udder, is considered evidence that a doe had raised fawns during the previous summer [35,36]. Our findings corroborated the Curtis et al. [7] report that five PZP-vaccinated deer delivered fawns in 2000. The fact that none of the six deer revaccinated in 2000 had lactated was a result of the selection of deer receiving the revaccination, not the treatment itself. The lac- 
tation evidence further confirms the return to normal fertility for PZP-vaccinated deer, even as some continue exhibiting oophoritis.

\subsection{Histological findings}

Ovarian inflammation resulting from PZP immunocontraceptive vaccinations have been extensively studied for many species [9-11,13,14,16-18,37-39]. However this is the first report of eosinophilic oophoritis in ovaries from PZP-treated white-tailed deer. We documented both B-cell humoral and T-cell response from the same injection formula, and we were also able identify reproductive recovery in deer still experiencing eosinophilic oophoritis. The two most striking results from the necropsied deer were: (1) the widespread documentation of eosinophilic oophoritis in PZP-vaccinated deer, and (2) the reduced number of normal secondary follicles in females without oophoritis that were revaccinated in 2000.

Oophoritic inflammation of the ovary, in our study, specifically describes the infiltration of eosinophils (and to lesser extent neutrophils) into the theca interna across the basement membrane, and into the cumulus oophorus, or zona granulosa layer. However, it appears that apoptosis (a hallmark of follicular atresia) is necessary before eosinophils progress through the theca interna. Eosinophils were never seen within the lumen of the follicle until the glassy membrane was first formed. Also, this inflammation was restricted to secondary and Graafian follicles; which was particularly interesting because the oocytes of the primary follicles were likewise surrounded by the zona pellucida (ZP). Multifocal aggregates of small lymphocytes were also commonly seen in the ovarian parenchyma (but not in the follicles). Although ovaries are not considered to provide a distinct morphologic barrier from the immune system [18,40], it appeared that the $\mathrm{ZP}$ was protected by the ovary from eosinophilic attack until ovulation or atresia. This supports the observations by McShea et al. [4] who noted neutrophils in atretic follicles, but not eosinophils.

In humans, eosinophils are inflammatory cells which develop in the bone marrow under the influence of several T-lymphocyte produced cytokines (IL-3, IL-5) [41,42]. They are activated by platelet-activating factor and the split products of the complement system (C5a, C3a, C4a) [43-45]. These eosinophils then migrate to sites of inflammation within specific tissues under the influence of various chemokines including eotaxin 1-3 (CCL11, CCL 24, CCL 26) secreted by fibroblasts $[41,46,47]$. At the site of inflammation, eosinophils release cationic and basic proteins, or reactive oxygen species, which leads to cellular death and simultaneous release of various chemokines, including MIP-1a (CCL3), RANTES (CCL5), and IL-8 (CXCL8) $[41,48,49]$. Thus eosinophils, in addition to an effector function, control their own accumulation as well as the recruitment of other leukocytes such as T cells, monocytes, neutrophils, and basophils [42]. Observations made on deer in this study indicated that ovarian ZP antigens presented to the immune system stimulated release of chemokines, which attracted eosinophils. The eosinophils then modulated the subsequent inflammatory response in the ovary.

We observed that 2000 PZP revaccinates had the greatest reduction in secondary follicles for those deer that lacked eosinophilic infiltration. This is best explained by an antibody-mediated attack against the $\mathrm{ZP}$ antigens, resulting in complement-mediated destruction, where T-helper cells secreted IL-4 and IL-10, enhanced B-cell production of antibodies, and interfered with the T-cell production of cytokines necessary for an inflammatory response. Thus, cellular events occurring within the ovary following PZP vaccination set the stage for primarily antibody-mediated activity, or cellular inflammation, but not both at the same time [30].

The observation that the eosinophils only occurred during atresia signified that oophoritis is not a sign of impeded ovarian function, but rather indicative of normal ovulation. Such an observation could be expected in successful contraception of deer when females display typical cyclic behavior. The question then would be: does the oophoritis cause pain or distress to the deer? Observations of good to excellent body condition for most deer in our study would imply that they were not impaired by PZP vaccination.

Conversely, half of the 2000 PZP revaccinates had significantly fewer normal secondary follicles and no eosinophilic invasion. Such follicular deterioration has been associated with inhibited ovarian function, abnormal cycling, or suppressed progesterone levels observed in many species $[9,11,14,16,18,38]$.

\subsection{Anomalies}

As for any species, reproductive anomalies can arise. A small number of women experience infertility due to premature ovarian failure from autoimmune oophoritis distinguished by ovarian lymphocyte infiltrates [17,18,50]. Similarly, we identified a control female (deer no. 84) maintained in the same environment with exposure to reproductively active males similar to other female deer on trial, yet failed to produce fawns during the course of the field study. The human case described by Page et al. [50] was determined to be eosinophilic perifolliculitis and tested positive for serum antiovarian antibodies. Similar to the human case, this infertile doe had an eosinophilic infiltrate in one of her ovaries without any treatment or sham injection, indicating self-induced autoimmune activity.

It is noteworthy that deer number 159 maintained a titer of 1:128,000 2 years post-vaccination, and had no injection site lesions. Miller et al. [15] observed similar prolonged immunocontraceptive efficacy and high titers, indicating the potential for continued self-inoculation each fall as normal ovulation resumed. Miller et al. [51] offered that variations in the residual immune response and physiological, morphological, or pathological differences among deer receiving identical treatments are likely due to genetic differences among individual animals from the same population. 


\section{Summary}

Many factors affect the success and potential pathology associated with an immunocontraceptive vaccine, including formulation of the immunogen, concentration of the immunogen, adjuvant used, and species treated. Therefore, before judgments can be made concerning the effectiveness and health risks associated with a given vaccine for a particular species, adequate evaluation must be conducted.

Deer vaccinated with PZP in this study continued to exhibit eosinophilic oophoritis 2 years after the last booster injection, including some deer that had already returned to normal fertility. The long-term health implications resulting from the Curtis et al. [7] vaccination protocol and associated pathologies are still unknown, and further study is advisable.

Observation of deer with bone marrow fat depletion, at a time of year when they should have their maximum energy reserves prior to winter, is an important concern. In climates with severe winters and deep snow, deer exhibiting reduced bone marrow fat during late summer and fall could be at risk for malnutrition and death if harsh conditions are prolonged. Hence, regardless of any possible connection to the PZP vaccine, continued effort to find the cause and extent of this condition should be a research priority, especially for deer herds in northern climates.

\section{Acknowledgements}

This project was successful because of the dedication and hard work provided by our friend and colleague R. Pooler. We are all saddened by his untimely passing, and are richer for time he spent with us. This project was supported by the USGS-Biological Resources Division- New York Cooperative Fish and Wildlife Research Unit, the New York State Department of Environmental Conservation, and the USDA National Wildlife Research Center. We appreciate helpful review comments from M. Smith, College of Veterinary Medicine, and technical support from M. Ashdown, Department of Natural Resources, Cornell University.

\section{References}

[1] Barber MR, Fayrer-Hosken RA. Evaluation of somatic and reproductive immunotoxic effects of the porcine zona pellucida vaccination. J Exp Zool 2000;286(6):641-6.

[2] Sacco AG. Zona pellucida: current status as a candidate antigen for contraceptive vaccine development. Am J Reprod Immunol Microbiol 1987;15(4):122-30.

[3] Frank KM, Lyda RO, Kirkpatrick JF. Immunocontraception of captive exotic species: IV. Species differences in response to the porcine zona pellucida vaccine, timing of booster inoculations, and procedural failures. Zoo Biol 2005;24(4):349-58.

[4] McShea WJ, Monfort SL, Hakim S, Kirkpatrick J, Liu I, Turner JW, et al. The effect of immunocontraception on the behavior and reproduction of white-tailed deer. J Wildl Manag 1997;61(2):560-9.
[5] Miller LA, Crane K, Gaddis S, Killian GJ. Porcine zona pellucida immunocontraception: long-term health effects on white-tailed deer. J Wildl Manag 2001;65(4):941-5.

[6] Rutberg AT, Naugle RE, Thiele LA, Liu IKM. Effects of immunocontraception on a suburban population of white-tailed deer Odocoileus virginianus. Biol Conserv 2004;116(2):243-50.

[7] Curtis PD, Pooler RL, Richmond ME, Miller LA, Mattfeld GF, Quimby FW. Comparative effects of GnRH and porcine zona pellucida (PZP) immunocontraceptive vaccines for controlling reproduction in white-tailed deer (Odocoileus virginianus). Reprod Suppl 2002;60: 131-41.

[8] Kirkpatrick JF, Rutberg AT. Fertility control in animals. In: Salem DJ, Rowan AN, editors. The state of the animals. 1st ed. Washington, DC: Humane Society Press; 2001. p. 183-98.

[9] Dunbar BS, Lo C, Powell J, Stevens VC. Use of a synthetic peptide adjuvant for the immunization of baboons with denatured and deglycosylated pig zona pellucida glycoproteins. Fertil Steril 1989;52(2):311-8.

[10] Lou YH, Bagavant H, Ang J, McElveen MF, Thai H, Tung KS. Influence of autoimmune ovarian disease pathogenesis on ZP3 contraceptive vaccine design. J Reprod Fertil 1996;50(suppl.):159-63.

[11] Mahi-Brown CA, Yanagimachi R, Nelson ML, Yanagimachi H, Palumbo N. Ovarian histopathology of bitches immunized with porcine zonae pellucidae. Am J Reprod Immunol Microbiol 1988;18(3):94-103.

[12] Millar SE, Chamow SM, Baur AW, Oliver C, Robey F, Dean J. Vaccination with a synthetic zona pellucida peptide produces long-term contraception in female mice. Science 1989;246(4932): 935.

[13] Rhim SH, Millar SE, Robey F, Luo AM, Lou YH, Yule T, et al. Autoimmune disease of the ovary induced by a ZP3 peptide from the mouse zona pellucida. J Clin Invest 1992;89(1):28-35.

[14] Skinner SM, Mills T, Kirchick HJ, Dunbar BS. Immunization with zona pellucida proteins results in abnormal ovarian follicular differentiation and inhibition of gonadotropin-induced steroid secretion. Endocrinology 1984;115(6):2418-32.

[15] Miller LA, Johns BE, Killian GJ. Long-term effects of PZP immunization on reproduction in white-tailed deer. Vaccine 2000;18(5-6):568-74.

[16] Stoops MA, Liu IK, Shideler SE, Lasley BL, Fayrer-Hosken RA, Benirschke K, et al. Effect of porcine zonae pellucidae immunisation on ovarian follicular development and endocrine function in domestic ewes (Ovis aries). Reprod Fertil Dev 2006;18:667-76.

[17] Barber MR, Fayrer-Hosken RA. Possible mechanisms of mammalian immunocontraception. J Reprod Immunol 2000;46(2):103-24.

[18] Dunbar BS, Prasad S, Carino C, Skinner SM. The ovary as an immune target. J Soc Gynecol Invest 2001;8(suppl. 1):S43-8.

[19] Munson L, Harrenstien LA, Acton AE, Graham PA, Chassy LM, Kirkpatrick JF. Immunologic responses and adverse reactions to Freund's-adjuvanted porcine zona pellucida immunocontraceptives in domestic cats. Vaccine 2005;23(48-49):5646-54.

[20] Skinner SM, Killian GJ, Miller LA, Dunbar BS. Characterization of antigenicity and immunogenicity patterns of native and recombinant zona pellucida proteins in the white-tailed deer (Oidocoileus virginianus). Reproduction 1994;101(2):295-303.

[21] Dunbar BS, Raynor BD. Characterization of porcine zona pellucida antigens. Biol Reprod 1980;22(4):941-54.

[22] Dunbar BS, Wardrip NJ, Hedrick JL. Isolation, physicochemical properties, and macromolecular composition of zona pellucida from porcine oocytes. Biochemistry 1980;19(2):356-65.

[23] Severinghaus CW. Tooth development and wear as criteria of age in white-tailed deer. J Wildl Manag 1949;13(2):195-216.

[24] Beaver BV, Reed W, Leary S, McKiernan B, Bain F, Schultz R, et al. Report of the AVMA panel on euthanasia. J Am Vet Med Assoc 2001;218:669-96.

[25] Cheatum EL. Bone marrow as an index of malnutrition in deer. N Y State Conservationist 1949:19-22. 
[26] Rudolph BA, Porter WF, Underwood HB. Evaluating immunocontraception for managing suburban white-tailed deer in Irondequoit, New York. J Wildl Manag 2000;64(2):463-73.

[27] Halls LK. White-tailed deer: ecology and management. Harrisburg, PA, USA: Stackpole Books; 1984.

[28] Verme LJ, Ozoga JJ. Effects of diet on growth and lipogenesis in deer fawns. J Wildl Manag 1980;44:315-24.

[29] Verme LJ, Ozoga JJ. Influence of protein-energy intake on deer fawns in autumn. J Wildl Manage 1980;44:305-14.

[30] Janeway Jr CA, Travers P. Immunobiology. The immune system in health and disease. 2nd ed. New York: Current Biology Lid/Garland Publishing Inc.; 1997.

[31] Broderson JR. A retrospective review of lesions associated with the use of Freund's adjuvant. Lab Anim Sci 1989;39(5):400-5.

[32] Kleinman NR, Kier AB, Diaconu E, Lass JH. Posterior paresis induced by Freund's adjuvant in guinea pigs. Lab Anim Sci 1993;43(4):364-6.

[33] Malaga CA, Weller RE, Roger Broderson J, Gozalo AS. Tuberculosislike lesions arising from the use of Freund's complete adjuvant in an owl monkey (Aotus sp.). J Med Primatol 2004;33(2):109-12.

[34] Rigdon RH, Schadewald T. Bacteriological and pathological study of animals given Freund adjuvant. Appl Environ Microbiol 1972;24(4):634-7.

[35] Keyser PD, Guynn DC, Hill HS. Population density-physical condition relationships in white-tailed deer. J Wildl Manag 2005;69(1):356-65.

[36] Miller KV, Marchinton RL. Quality whitetails: The why and how of quality deer management. Mechanicsburg, PA, USA: Stackpole Co.; 1995.

[37] Gupta SK, Jethanandani P, Afzalpurkar A, Kaul R, Santhanam R. Prospects of zona pellucida glycoproteins as immunogens for contraceptive vaccine. Hum Reprod Update 1997;3(4):311-24.

[38] Sacco AG, Yurewicz EC, Subramanian MG, Lian Y, Dukelow WR. Immunological response and ovarian histology of squirrel monkeys (Saimiri sciureus) immunized with porcine zona pellucida ZP3 $(\mathrm{Mr}=55,000)$ macromolecules. Am J Primatol 1991;24(1):15-28.

[39] Tung KS, Ang J, Lou Y. ZP3 peptide vaccine that induces antibody and reversible infertility without autoimmune oophoritis. Am J Reprod Immunol 1996;35(3):181-3.

[40] Dunbar BS. Ovarian antigens and infertility. Am J Reprod Immunol 1989;21(1):28-31.
[41] Elsner J, Escher SE, Forssmann U. Chemokine receptor antagonists: a novel therapeutic approach in allergic diseases. Allergy 2004;59(12):1243-58.

[42] Elsner J, Kapp A, Virchow Jr JC, Luttmann W. Eosinophils: quo vadis? The role of eosinophils in the chemokine network of allergy. Mod Aspects Immunobiol 2001;2(1):18-24.

[43] Czech W, Dichmann S, Herouy Y, Rheinen H, Elsner J, Kapp A, et al. Distinct amplification of the C5a-receptor pathways in normodense and hypodense eosinophils of patients with atopic dermatitis. Scand J Immunol 2001;53:235-9.

[44] Elsner J, Oppermann M, Czech W, Dobos G, Schopf E, Norgauer J, et al. $\mathrm{C} 3 \mathrm{a}$ activates reactive oxygen radical species production and intracellular calcium transients in human eosinophils. Eur J Immunol 1994;24(3):518-22.

[45] Kroegel C, Yukawa T, Dent G, Venge P, Chung KF, Barnes PJ. Stimulation of degranulation from human eosinophils by platelet-activating factor. J Immunol 1989;142(10):3518-26.

[46] Ponath PD, Qin S, Ringler DJ, Clark-Lewis I, Wang J, Kassam N, et al. Cloning of the human eosinophil chemoattractant, eotaxin expression, receptor binding, and functional properties suggest a mechanism for the selective recruitment of eosinophils. J Clin Invest 1996;97(3): 604-12.

[47] Shinkai A, Yoshisue H, Koike M, Shoji E, Nakagawa S, Saito A, et al A novel human CC chemokine, eotaxin-3, which is expressed in IL4-stimulated vascular endothelial cells, exhibits potent activity toward eosinophils. J Immunol 1999;163(3):1602-10.

[48] Olszewska-Pazdrak B, Casola A, Saito T, Alam R, Crowe SE, Mei F, et al. Cell-specific expression of RANTES, MCP-1, and MIP-1a by lower airway epithelial cells and eosinophils infected with respiratory syncytial virus. J Virol 1998;72(6):4756-64.

[49] Yousefi S, Hemmann S, Weber M, Holzer C, Hartung K, Blaser K, et al. IL-8 is expressed by human peripheral blood eosinophils. Evidence for increased secretion in asthma. J Immunol 1995;154(10): 5481-90.

[50] Page K, Pagidas K, Derosa MC, Quddus MR. Eosinophilic perifolliculitis presenting as a painful cystic ovarian mass in a woman with fibromyalgia: a case report. J Reprod Med 2006;51(2):141-4.

[51] Miller LA, Johns BE, Killian GJ. Immunocontraception of white-tailed deer with GnRH vaccine. Am J Reprod Immunol 2000;44(5):266-74. 